\title{
China's Grain Production under Bottom-up and Top-down Patterns of Agricultural Reforms: A Typical Case Study in Anhui Province
}

\author{
Wei Shui ${ }^{1} \&$ Gregory Veeck ${ }^{2}$ \\ ${ }^{1}$ Department of Eco-agriculture and Rural Development, Sichuan Agricultural University, Chengdu, China \\ ${ }^{2}$ Department of Geography, Western Michigan University, Kalamazoo MI, USA \\ Correspondence: Wei Shui, Department of Eco-agriculture and Rural Development, Sichuan Agricultural \\ University, Chengdu 611130, China. E-mail: shuiweiman@163.com
}

Received: March 19, 2012 Accepted: March 29, 2012 Online Published: May 18, 2012

doi:10.5539/jgg.v4n2p22 URL: http://dx.doi.org/10.5539/jgg.v4n2p22

\begin{abstract}
By reviewing the changes in China's agricultural reforms since 1978 from the perspective of its initiator, guide, designer and organizer, the author defines two stages of agricultural reforms: one is the bottom-up stage in early $1980 \mathrm{~s}$ and the other is the top-down stage after China's entry into WTO. With a comprehensive quantitative-qualitative analysis of grain production of Anhui Province in response to the full implementation of the bottom-up and top-down agricultural reforms, conclusions are drawn as follows: 1) grain production growth has made great contributions to solving China's grain food crisis during the bottom-up agricultural reform as well as to China's grain food security at the top-down reform stage; 2) in general, among all sorts of socioeconomic factors, arable land, chemical fertilizers and mechanization have exerted the most significant influence on grain yield; 3) in contrast, chemical fertilizers and irrigation played the most critical role in early 1980s, followed by arable land and mechanization, while at the stage of the top-down agricultural reform, the main influencing factors include arable land, mechanization, chemical fertilizers and irrigation in sequence; 4) along with the increasing trend of agricultural specialization and clustering after the entry into WTO, irrigation and mechanization have made less contribution to grain production growth, while chemical fertilizers have been under the law of diminishing returns; 5) natural disasters including serious droughts and floods have been playing a special role in the stagnation and fluctuation of grain growth. Currently, with the leadership of government and the participation of peasants themselves, the negative influences exerted by natural disasters have been relieved a lot.
\end{abstract}

Keywords: bottom-up, top-down, agricultural reform, grain production, Anhui province, China

\section{Introduction}

As one of the basic food on our planet, grain has always been the focus widely discussed by every nation and its people since the second half of the $20^{\text {th }}$ century. Only a handful of countries can produce enough grain for export after feeding their own people while most countries are limited by their arid land, mountains, etc in their territory (Brown \& Halweil, 1998). Early in 1981, it was argued by Barr in his article published in Science that by 1990, the developed world will have 24 percent of the world's population, 50 percent of the world's grain consumption and produce nearly three times on a per capita basis as much grain as the developing countries which account for three-fourths of the world's population (Barr, 1981). As a serious result, some developing countries lack grain for their basic livelihoods in the world grain situation and international price variability (Barr, 1981; Blandford, 1983). In addition, since 1990, the growth rate in world grain production has been lower than that in population regardless of the rapid growth in the former during 1966 to 1990 (Khush,1999). If this trend continues, the 21st century will be increasingly severe. Anyway, there is no doubt that world's grain has been threatened by a series of factors including the growing population, farmland reduction, natural disasters, soil degradation, global climate changes, ecological and environmental constraints, adaptability of advanced agricultural technology, trade barriers, socio-economic systems and so on (Thompson, 1975; Rozelle \& Veeck, 1997; Parry et al., 1999; Khush, 1999; Battisti \& Naylor, 2009; Neumann et al., 2010; Rode, 2011).

In 1990s, people in US and other developed countries aroused large-scale concerns about developing China's ability to feed itself. Lester Brown, President of WORLD WATCH Institute, who is said to be "one of the world's most influential thinkers" by the Washington Post, published an article titled "Who Will Feed China?" in 1994 
and went on to compose a book in 1995 named "Who Will Feed China? Wake-up Call for a Small Planet" (Brown, 1994; 1995). In this book, he challenged China central government's view on China's grain prospect and showed that by taking into account some trend including China's rapid paving-over of cropland for industrialization and urbanization, its diminishing returns from the application of fertilizers, its rapidly increasing population by the equivalent of a new Beijing each year, and growing shortage of irrigation water, China was headed not toward a surplus but a large deficit in grain production - a situation that would severely jeopardize world food security by driving grain prices to a high level that a rising number of poor nations could never afford (Brown, 1995; Brown \& Halweil, 1998). After that, Brown's viewpoint soon began to be echoed by the mainstream media, academics and governments, including the New York Times with a nearly identical title"Good Earth is Squandered. Who'll Feed China?" three weeks later, international conferences and seminars in the ensuing months, The New York Review's publication of "Is There Enough Chinese Food?" and Scientific American's "Can China Feed Itself?" in 1996, and the MEDEA Study on the Future of Chinese Agriculture jointly issued by the NIC (National Intelligence Council) and CIA (Central Intelligence Agency) in January 1998 (Shenon, 1994; Smil, 1996; Prosterman et al., 1996; Brown \& Halweil, 1998). Of course, at that time, China central government and specialists also responded to Brown's perspective and argued in this grain issue (Wang et al., 1995; Xie, 1996; Chen, 1996).

Unlike the serious situation mentioned by Lester Brown, global grain production has increased dramatically during the past 50 years and China's grain production has kept a continuous 7-year growth from 2004 to 2010 according to China's official reports (Neumann et al., 2010). In 2008, per capita grain production of $404 \mathrm{~kg}$ in China, which doubled that of $195 \mathrm{~kg}$ in 1949, surpassing the world's average level. In 2005, 25 years' grain aid by Word Food Program came to an end, hence ending the history of China's chronic grain shortages and achieving a basic total balance. All the above data and facts indicate that China successfully feed $22 \%$ of the world's population with only $7 \%$ of the world's arable land so that China has created a great miracle in human history and played an active and irreplaceable role for the improvement of world food security.

Behind the aura of China's achievements in grain production, there are still some hidden threats and volatilities which are likely to shake world food security. Tiejun Wen's research shows that although grain production has generally followed the simultaneous growth of population as shown in the data related to the period from 1949 to 2002, there were two low-growth phases with greater volatility respectively in the disaster period from 1958 to 1965 and the soaring-price period from 1992 to 2001 (Wen, 2001). Especially during 1998 to 2003, mainly owing to the reduction of grain planting area, China's grain production dropped to the lowest level under the volatility since 1998 (Zhang et al., 2007; Fan \& Cheng, 2006). Some of China's scholars and foreign specialists on China's agricultural development studied the important influencing factors on China's grain production related to sown area, integrated nutrient and pest management, land productivity, intensified land management, technical efficiency, water shortage, utilization of water and soil resources, environmental degradation, disasters, global environmental changes, rural land policies and agricultural reforms (Carter \& Zhong, 1988; Wang et al., 1996; Rozelle \& Veeck, 1997; Brown \& Halweil, 1998; Yao \& Liu, 1998; Yang, 1999; Verburg et al., 2000; Wen, 2001; Zhang \& Li, 2006; Cui \& Kattumuri, 2010; Veeck \& Shui, 2011).

But for a number of China's grain growth factors, institutional and policy factors have played a leading role in grain production since 1949. After the land reform accomplished in 1952 and the people's commune system implemented during the 1952-1978 period, China adopted a contracted household responsibility system, which was proved to be especially effective for increasing grain output and peasants' income (Yao, 1994; Rozelle \& Veeck, 1997; Rozelle \& Sumner, 2003; Zhang et al., 2006). During the period of China's agricultural reform from 1978 to 1985, the rapid growth of grain yield was mainly attributed to the land-based contracted household responsibility system firstly implemented in the Chinese history by China government (Carter \& Zhong, 1988; Wen, 2003; Veeck \& Shui, 2011). From 1978 to 1984, agricultural output gained an average annual growth rate of $7.7 \%$, which is $5 \%$ higher than that from 1953 to 1978 . With the full implementation of the contracted household responsibility system in 1985, China's grain output rose to 379.1 billion kilograms, higher than 304.7 billion kilograms in 1978.

Unfortunately, after the agricultural reform in early 1980s, China preserved the urban-rural dichotomous economy formed in the people's commune era which placed agriculture on the secondary position (Zhang et al., 2006). With the low efficiency of agricultural sector and inadequate government support, China's urbanization and industrialization greatly stimulated a large number of young farmers to leave their farmland for cities and factories, which directly led to China's grain growth hovering and laggard comprehensive growth from 1986 to 2003 (Wen, 2001; Ho et al., 2004; OECD, 2005; Zhai \& Liu, 2008; Veeck \& Shui, 2011).

In fact, against the institutional background of China, continuous grain growth is also closely related to a series 
of agricultural reform policies adopted by China central government since 2003, especially after the entry into WTO. In contrast, the period after China's entry into WTO significantly shows more government involvement at all levels and a series of national policies of calling for agriculture to be supported by industry and the urban area, particularly by the central government, hence reflecting new ideas and perspectives concerning the role of the farm sector and farming families in economic development strategies for rural areas (Chuang, 2000; Duan \& Dwyer, 2008; Veeck, 2009; Veeck \& Shui, 2011). During the era after the entry into WTO, with the establishment of its basic strategy of "coordinated urban-rural development" as well as its basic principle of "giving more to peasants, asking for less from peasants, more activating for peasants", China central government has taken a series of more direct, powerful and effective rural policies. For example, since 2003, in order to arouse peasants' enthusiasm to improve grain output and expand grain planting area, central government has formulated a series of policies, including agricultural tax deduction, grain subsidies, seed subsidies, machinery purchase subsidies, and so on. What's more, these grain subsidies have been on the rise every year since 2003 . On September 29, 2005, China government abolished the regulations on agricultural tax, which had been in existence for 2600 years in China's history (Xinhua News Agency, 2005). After 2006, the central government began to adopt "the New Socialist Countryside Policy" and "Comprehensive Rural Reform" involved not only in agriculture and economic field, but also in political, social and cultural aspects, which stressed the importance of democratic election, democratic decision-making, democratic management and supervision in villages. As a result, after 5 years' grain growth, China's grain output in 2008 reached 528.5 billion kilograms (Figure 1). Although we need more supporting facts, it can be seen that one of the most important reasons for the grain growth during the 2003-2008 period should be derived from "China's quiet agricultural reforms" after the entry into WTO, named by Prof. Gregory Veeck and Wei Shui (Veek \& Shui, 2011). Based on the above, we can reasonably conclude that there are significant differences between the agricultural reforms in the 1980s and the beginning of the $21^{\text {st }}$ century since the contracted household responsibility system originated in Xiaogang Village of Anhui Province reflects the bottom-up agricultural reform while a series of comprehensive agricultural reform of China in the latter period has been arranged and guided by China central government with apparent top-down characteristics.

Whereas, it is very interesting that Anhui province in China is the birthplace of national agricultural reform in the $1980 \mathrm{~s}$ and the beginning of the $21^{\text {st }}$ century. For China's agricultural reforms, Anhui has played a pioneering role since 1978 as former China's president Deng Xiaoping once said in the spring of 1992, "China's reform began in rural areas and China's rural reform started from Anhui Province" (Xinhua News Agency, 2007). With Anhui being a typical agricultural province, each agricultural reform here, known as the mirror of China's rural reform, is called "Anhui mode" and has led rural China to make steady progress. In 1978, 18 peasants in Xiaogang Village of Fengyang county in Anhui, by signing a secret land contract related to individual criminality to abandon the "communal pot", ushered in the rural reform of China's contracted household responsibility system. In 2000, China central government once again decided to make Anhui Province take the lead in carrying out the experimental rural reform on agricultural taxes and administrative charges. In 2005, Anhui Province again became the first experimental province to conduct Comprehensive Rural Reforms. It is worth pointing out that the contracted household responsibility system obtained its full implementation in 1982 here, 3 years prior to other provinces and the full implementation of the agricultural tax \& fee reform in 2000 and Comprehensive Rural Reforms in 2005 also goes 2-4 years ahead of other provinces.

From 1978 to 2008, Anhui's grain output has generally been on an increasing trend just like that of whole China (Figure 1), with the Pearson correlation coefficient of 0.908 at 0.01 level for the whole 29 -year period. Due to the implementation of land-based contracted household responsibility system during the period from 1978 to 1985, grain production was sharply increased from 14.8 billion kilograms in 1978 to 21.7 billion kilograms in 1985. Given that the rural reform of agricultural taxes and fees in 2000 and comprehensive rural reform in 2005 also took several years to fully implement, the actual growth of Anhui's grain production has been taken place since 2003, which is a serious natural disasters year in history. Figure 1 shows that along with Anhui's grain production growth for 5 years, the total grain production of Anhui in 2008 topped to 30.2 billion kilograms (Figure 2) and reached 30.3 billion kilograms in 2009 which was 4.8 times of that in 1949 (6.4 billion kilogram). At present, Anhui's grain production ranked $6^{\text {th }}$ in China's inter-provincial level and transferred 5 billion kilograms of grain to other provinces each year has been made greater contributions to national grain food security. Anhui's grain output increased by leaps and bounds from $63.5 \mathrm{~kg} / \mathrm{mu}$ in 1949 to $307 \mathrm{~kg} / \mathrm{mu}$ in 2008 . Among them, wheat production jumped from less than $40 \mathrm{~kg} / \mathrm{mu}$ in 1949 to $333 \mathrm{~kg} / \mathrm{mu}$ in 2008, rice production from $131 \mathrm{~kg} / \mathrm{mu}$ to $407 \mathrm{~kg} / \mathrm{mu}$, maize production from $62.5 \mathrm{~kg} / \mathrm{mu}$ to $271 \mathrm{~kg} / \mathrm{mu}$. It can be seen from above that the bottom-up and top-down agricultural reforms of Anhui province both in 1980s and 2000s are very similar with those at the national level. 
In short, taking the 61 counties of Anhui province as an example as well as a mirror of China's agricultural reforms under the background of the bottom-up and top-down agricultural reforms, this research aims at analyzing the relation between Anhui's grain production and economic development, making a comparison of the socio-economic influencing factors on grain production before and after each stage of agricultural reforms, assessing the impact of natural disasters on grain production, and in particular analyzing whether the grain growth positively respond to bottom-up and top-down agricultural reforms and what differences can be detected.

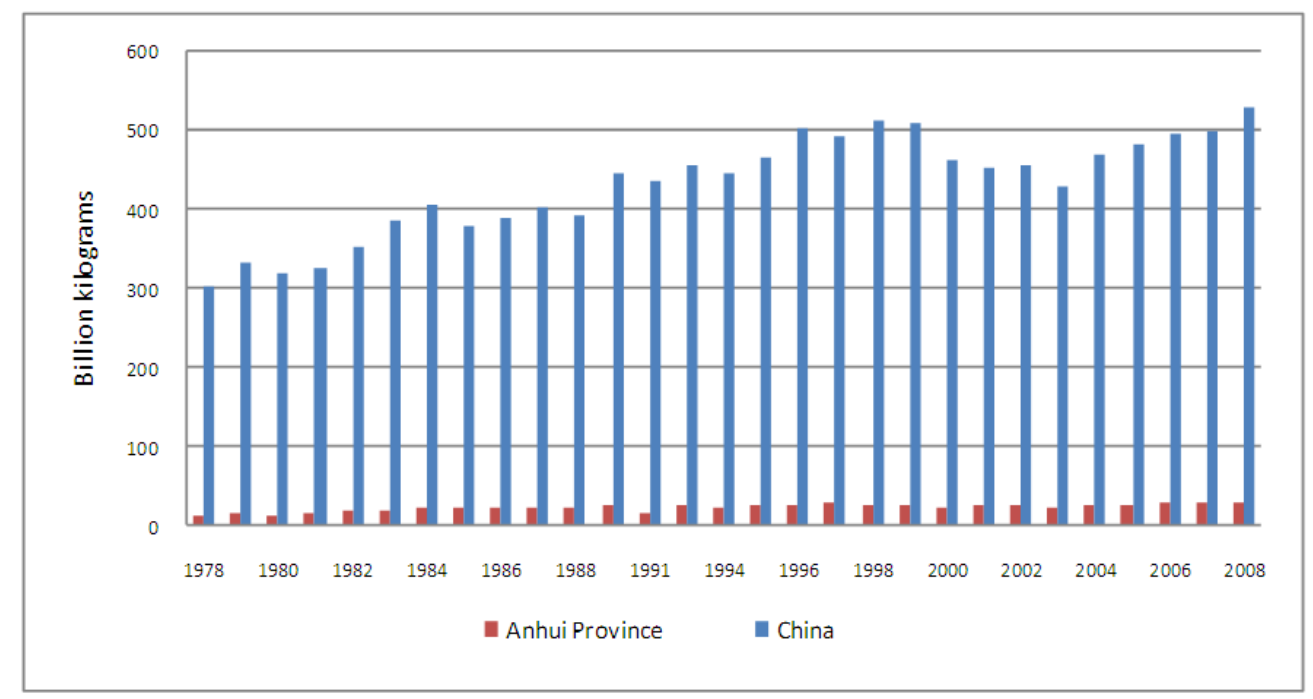

Figure 1. Grain production of China and Anhui province, 1978-2008

Source: Mapped by authors from NBS, 1979-2009

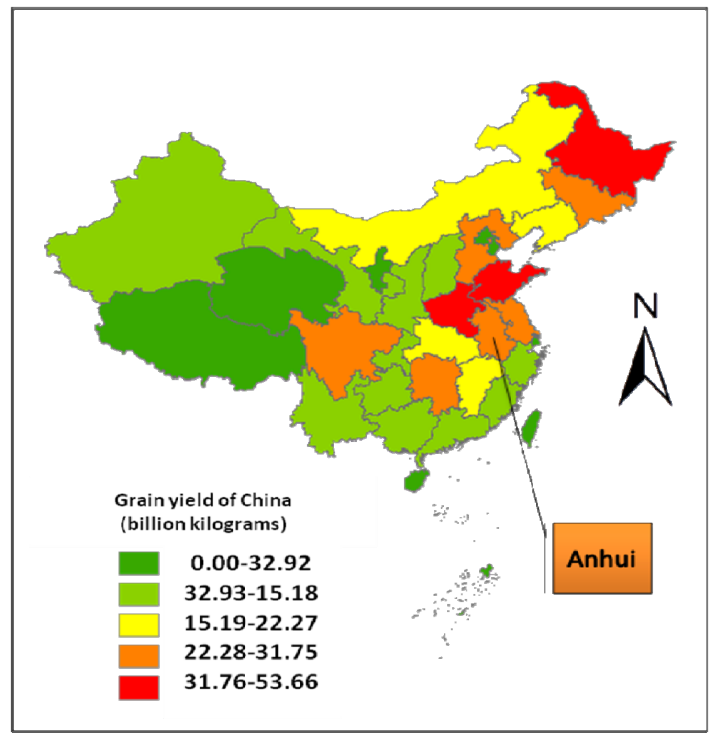

Figure 2. China's grain yield (billion kilograms) by province, 2008

Source: Mapped by authors from NBS, 2009

\section{Study Area, Methodology and Data}

\subsection{Study Area}

Anhui Province, one of the eastern provinces of China, lies in the hinterland of Yangtze Delta and the transitional area between the temperate zone and the subtropical zone (Figure 3). The north of the Huaihe River possesses a 
half-moist monsoon climate typical of warm temperate zone while the south of the Huaihe River possesses a subtropical moist monsoon climate. Anhui covers an area of 139,600 square kilometers with the population of 61.31 million by the end of 2009. The landforms in Anhui are very complicated with plains, hills and mountains covering $1 / 3$ of its area respectively. The Yangtze River and Huaihe River flow through the province and divide it into three main natural areas. Chaohu Lake is one of the five great freshwater lakes in China, with an area of 800 square kilometers. The climate condition is suitable for various kinds of crops with an average annual agricultural temperature of 14-17 degrees Celsius, 700-1700 mm's rainfall and 200-250 days' frost-free period. Under normal circumstances, there is an agricultural cultivated area of $8,000,000$ hectares with $65 \%$ of its products being grain and $35 \%$ economic and other products. Grain products mainly include wheat (accounting for $80 \%$ ), rice, maize and sweet.

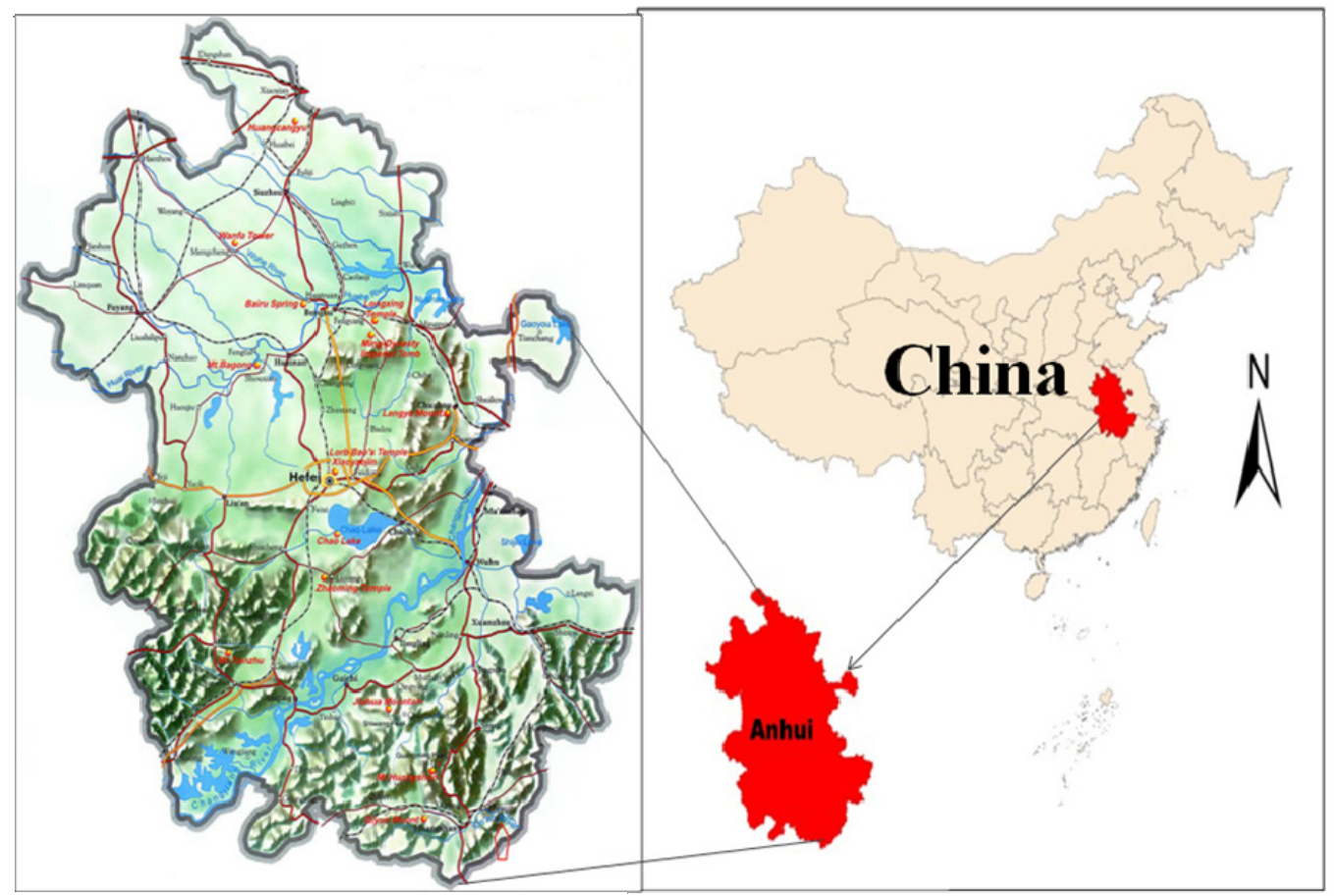

Figure 3. Location of Anhui Province in China

\subsection{Methodology and Data}

Based on a microcosm of China's grain production in bottom-up and top-down agricultural reform, this paper takes the 61 counties in Anhui Province as the study area, not including the urban area of its 17 urban districts. According to the available data, the period from 1980 to 1985 can be defined as the stage of the bottom-up agricultural reform, while the period after China's entry into WTO can be seen as the stage of the top-down agricultural reform. In order to observe and analyze Anhui's grain production in response to the full implementation of the two stages of agricultural reforms, the following methods and data will be utilized: 1) Analyze the correlation between Anhui's grain production and its local economic development in Anhui's inter-county level, including the relationship between Anhui's grain production and household income; 2) By comparing the beginning of each stage (or the period prior to it) and the period after the effective implementation of agricultural reforms, the author detects the changes in the socioeconomic influencing factors for grain production with Pearson correlation analysis so as to observe the effects and intensity of grain production in response to the two stages of agricultural reform. Specifically speaking, the author studies the changes in the socioeconomic influencing factors during the bottom-up agricultural reform from 1980 and 1985 as well as during the top-down agricultural reform from 1999 to 2008; 3) Because the data of grain production per unit of area at the inter-country level are not available, the characteristics of simultaneous growth between rural population and total output of grain can be based on to assume the equal distribution of cultivated land to each farmer in different counties. Therefore, the author uses (peasants) per capita grain production as an key indicator 
to analyze the Pearson correlation between per capita grain production and other relevant socioeconomic indicators; 4) Using spatial interpolation method of GIS and Pearson correlation, this paper also studies the relationship between grain output and climate so as to determine the impact of climate on grain production and whether climate weakens the effect of the rural reform policies. In addition, 5) It is worth pointing out that the analytical data used in this paper all come from China's official statistical yearbooks and other officially published data.

\section{Results and Analysis}

\subsection{Grain Production and Socioeconomic Development under Bottom-up and Top-down Patterns}

At the two stages of Anhui's agricultural reforms, Anhui's grain production showed remarkably different roles in facilitating regional economic development. After the 1952-1978 period with insufficient food to feed people, since the first implementation of the contracted household responsibility system in 1978, grain production has given its top priority to providing adequate food and clothing for peasants and further making them get out of poverty. With the propelling force of the farmland-based contracted household responsibility system, significant changes have exerted positive impacts on Anhui's grain production and socioeconomic development. In return, Anhui's grain yield has also made a great contribution to agriculture and regional economy. As the new master of farmland in the new situation in contrast to the people's commune system, peasants have greater enthusiasm for cultivation so that the key problem on how to have enough grain to feed people, which had puzzled China central government before 1980, has been nearly completely solved in the early 1980s. Consequently, the annual growth rate of grain yield in Anhui's 61 counties was 5.41\% from 1980 to 1985. The Pearson correlation coefficient between per capita agricultural output and per capita grain production was 0.877 , incorporated with that between per capita social gross output and per capita grain production (0.762), also showed the important role of agriculture in local economy, especially for that special era of the 1980s (Table 1). It is particularly interesting that since the primary objective of the agricultural reform is to provide enough grain to feed peasants themselves, grain for breeding pigs has been limited to a small proportion, as is shown in the Pearson correlation coefficient between per capita pork production and per capita grain production (0.266-0.289) (Table 1). In addition, most peasants had very little savings compared with those now. As a result, an insignificant negative correlation $(\mathrm{P}<0.05)$ was observed for per capita deposits and per capita grain production in 1980 (Table 1).

Table 1. Pearson's correlation between per capita grain production and selected socioeconomic Indicators for Anhui's 61 counties, 1980 and 1985

\begin{tabular}{lcc}
\hline & Per capita grain production in 1980 & Per capita grain production in 1985 \\
\hline Per capita social gross output & -.179 & $.762\left(^{* *}\right)$ \\
Per capita agricultural output & - & $.877\left(^{* *}\right)$ \\
Per capita pork production & $.266\left(^{*}\right)$ & $.289\left(^{*}\right)$ \\
Per capita deposits & -.179 & - \\
\hline
\end{tabular}

** Correlation is significant at the 0.01 level (2-tailed); * Correlation is significant at the 0.05 level (1-tailed); $\mathrm{N}=61$ Source: Calculated by authors from NBS, 1981 and 1986

Out of the step of rapid economic growth of China and Anhui, Anhui's grain production has been experiencing a 12-year wandering period until 2003. From 2003 to 2008, Anhui's grain growth rate at the county level reached $10.92 \%$, significantly higher than that in the rapid growth period from 1980 to 1985 (5.41\%). Figure 4 shows that the grain production growth rate in northern Anhui in the 2003-2008 period is faster than that in southern Anhui which also achieved rapid progress compared with the period from 1980 to 1985. Interestingly enough, during the top-down rural reform, despite the ever-increasing grain production and the rise of national grain prices, the more grain was produced, the less impact it had on farmers' income and local economy. Table 2 shows that in 1999, per capita grain production is positively associated with the per capita income in the rural area with the correlation coefficient of 0.264 (Table 2). However, the positive correlation between 2008's grain production and the rural per capita income has become very weak with no statistical significance at the 0.05 level, regardless of the significant increasing positive correlations between the per capita cash income from household business and per capita grain production during the same period (Correlation coefficient is 0.313, 0.512 for 1999 and 2008 respectively ), as similarly shown in the positive correlations between per capita cash income from selling products and per capita grain production (Correlation coefficient is $0.285,0.543$ for 1999 and 2008 
respectively) (Table 2). Grain yield has a slight impact on local economy since the correlations between per capita GDP and per capita grain production became weaker from positive to negative from 1999 to 2008 without statistical significance (Table 2). In the same way, the correlations between grain and per capita public revenue as well as between grain and per capita retail sales of consumer goods were slightly negative from 1999 to 2008 , which is of statistical significance at the 0.05 level in 2008 (Table 2).

Table 2. Pearson's correlation between per capita grain production and selected socioeconomic Indicators for Anhui's 61 counties, 1999 and 2008

\begin{tabular}{lcc}
\hline & $\begin{array}{c}\text { per capita grain production } \\
\text { in } 1999\end{array}$ & $\begin{array}{c}\text { per capita grain production } \\
\text { in } 2008\end{array}$ \\
\hline Rural per capita income & $.264\left(^{*}\right)$ & .080 \\
Per capita cash income from household business & $.313(*)$ & $.512(* *)$ \\
Per capita cash income from selling products & $.285(*)$ & $.543(* *)$ \\
Per capita GDP & .209 & -.160 \\
Per capita public revenue & -.005 & $-.260\left(^{*}\right)$ \\
Per capita total retail sales of consumer goods & -.073 & $-.270(*)$ \\
\hline
\end{tabular}

** Correlation is significant at the 0.01 level (2-tailed); * Correlation is significant at the 0.05 level (1-tailed); N=61 Source: Calculated by authors from NBS, 2000 and 2009
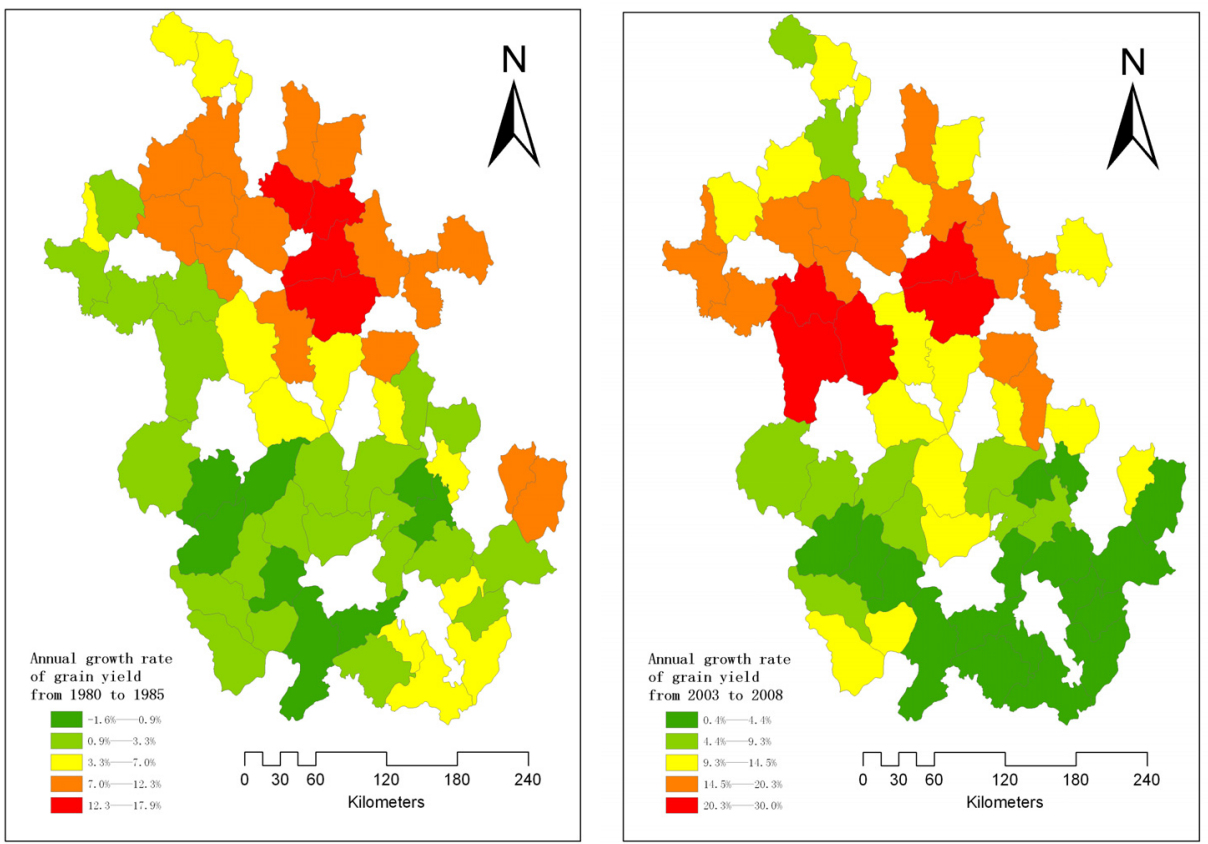

Figure 4. Anhui's annual growth rate of grain yield*, 1980-1985 and 2003-2008 * 61 counties of Anhui province, not included urban area of 17 urban districts in Anhui Source: Mapped by authors from NBS, 1981, 1986, 2004 and 2009

\subsection{The Socioeconomic Influencing Factors for Grain Production during the Bottom-up Agricultural Reform Period}

During the bottom-up agricultural reform from 1980 to 1985, what changes happened to grain production in 61 counties affected by some socioeconomic factors such as the amount of cultivated land, land productivity, irrigation, chemical fertilizers, mechanization and so on? Table 3 shows the correlations between grain production and several socioeconomic influencing factors from 1980 to 1985 . As to cultivated land, per capita cultivated land, incorporated with per capita grain planting area, is an important factor to affect per capita grain 
production since significant positive correlations ( $\mathrm{p}<0.01$ or greater) have been observed for per capita cultivated land and per capita grain planting area. Moreover, the marked increase in two correlation coefficients from 1980 to 1985 also indicates that the sown and cultivated acreage has a greater impact on grain production. In addition, the grain output per mu also has a significant impact on per capita grain production with significant positive correlation at the 0.001 level. But the correlation coefficient between the grain output per mu and per capita grain production (0.5-0.6) reveals the imbalance of per capita cultivated land with more in northern Anhui and less in the southern part (Table 3).

With regard to the county-level investments during grain cultivation, at the per capita level, the power of agricultural machinery, consumption of chemical fertilizers, irrigated area and electricity are positively associated with the output of grain from 1980 to 1985 . Among these factors, irrigation has a very significant positive impact on grain output where the correlation coefficient is high at 0.856 in 1980 and 0.738 in 1985 (Table 3). Since plains account for one-third of whole Anhui, and 1/3 area of hills are partially cultivated with the help of agricultural machinery, the degree of grain production mechanization here has been higher than western China and the foothill of eastern China since 1978. So per capita power of agricultural machinery is not only significantly associated with per capita grain production at the 0.001 level but also become better correlated in 1985 (Table 3). Similarly, Pearson's product moment correlation for per capita chemical fertilizers with per capita grain production also shows that chemical fertilizers have become increasingly important for improving grain output from 1980 to 1985 (Table 3). Thereafter, it cannot be neglected that electricity consumption is also an indispensable factor to enhance the output of grain. The increasing positive correlation $(p<0.001)$ from 1980 to 1985 shown in Table 3 also indicates that the utilization of electricity power is a luxury for most rural areas in Anhui in that era because of the lack of electricity power and power facilities. It is worth noting that chemical fertilizers per mu are also significantly $(\mathrm{p}<0.01)$ and positively correlated to per capita grain production in 1985 but not significantly $(\mathrm{p}>0.05)$ and negatively correlated to per capita grain production in 1980, which may indicates chemical fertilizers tend to increase returns at the original stage of agricultural development (Table 3).

On the other hand, the contribution of Multiple Crop Index (MCI) can't be ignored as well. Table 3 shows that the relationship between MCI and per capita grain production is significantly negative at the 0.05 level, and the significant negative correlation coefficient in 1985 is larger than that in 1980 (Table 3). Since the food grain and clothing issue got resolved in the agricultural reform of the contracted household responsibility system, except for grain cultivation, Anhui's peasants began to pursue eating and selling more other food such as vegetables and oil-bearing crops. So the higher MCI is, the lower grain yield is produced, especially in southern Anhui with less arable land and higher MCI (Figure 3).

Table 3. Pearson's correlation between grain production and influencing factors for Anhui's 61 counties, 1980 and 1985

\begin{tabular}{lcc}
\hline & $\begin{array}{c}\text { Per capita grain production } \\
\text { in } 1980\end{array}$ & $\begin{array}{c}\text { Per capita grain production } \\
\text { in } 1985\end{array}$ \\
\hline Per capita cultivated land & $.561(* *)$ & $.717(* *)$ \\
Per capita grain planting area & $.543(* *)$ & $.727(* *)$ \\
The rain output per mu & $.553(* *)$ & $.599(* *)$ \\
Per capita power of agricultural machinery & $.385(* *)$ & $.561\left(^{* *}\right)$ \\
Per capita irrigated area & $.856(* *)$ & $.738(* *)$ \\
Per capita chemical fertilizers & $.421(* *)$ & $.740\left(^{* *}\right)$ \\
Chemical fertilizers per mu & -.020 & $.358(* *)$ \\
Per capita electricity consumption & $.409(* *)$ & $.501(* *)$ \\
Multiple Crop Index(MCI) & $-.279(*)$ & $-.366(* *)$ \\
\hline
\end{tabular}

** Correlation is significant at the 0.01 level (2-tailed); * Correlation is significant at the 0.05 level (1-tailed); $\mathrm{N}=61$ Source: Calculated by authors from NBS, 1981 and 1986

\subsection{The Socioeconomic Influencing Factors for Grain Production in the Top-down Agricultural Reform}

Compared with the output of grain from 1980 to 1985, what changes have come from the comprehensive top-down agricultural reform after China's entry into WTO? Pearson's correlation between per capita grain 
production and the selected socioeconomic influencing variables for 1999-2008 is provided in Table 4. Among all sorts of influencing factors, the most significant positive indicator is grain planting area and cultivated land. Table 4 shows that Pearson correlation coefficient between per capita grain production and per capita cultivated land is greater than 0.8 in 2008, a little higher than that in 1999. In addition, the high-positive correlation up to 0.985 was put up for the improved quantity of grain and the increased planting area during the same period in 17 cities (lacking the data of 61 counties). It is obvious that with the shrinking of Anhui's cultivated land along with rapid urbanization and industrialization, which is a little similar to the situation in developed eastern China, the most important approach to increase grain yield is to make full use of cultivated land and expand the sown area of grain by reusing abandoned arable land with the policies adopted to stimulate agricultural development in 2000s.

On one hand, the law of diminishing returns is in operation as more chemical fertilizers are applied to shrinking land (Yao \& Liu, 1998); on the other hand, with increasing emphasis on China's grain food security since the late 20th century, the consumption of chemical fertilizers is on a slow rising trend with a growth rate of $2.3 \%$ from 1999 to 2008 , which is especially well below the grain growth rate $(9.72 \%)$ during the same period. As a result, the increased chemical fertilizers are very limited to increase grain production, which can get proved by Pearson correlation coefficient $(0.72$ and 0.7$)$ between per capita grain production and per capita consumption of chemical fertilizers during the period from 1999 to 2008 which is similar to that 1985 regardless of the time span of 23 years (Table 3 and Table 4). Anyway, the chemical fertilizers still played an important role in promoting Anhui's grain yield during the top-down agricultural reform.

For the degree of mechanization in recent decades is much higher than that between 1980 and 1985, particularly with the stimulating force from the policy of heavy agricultural subsidies in 2003, Anhui's grain production has been a little more affected by agricultural mechanization. Table 4 incorporated with Table 3 shows that the relationship between per capita grain production and per capita power of agricultural machinery is more significantly positive in 1999 and 2008 with the Pearson correlation coefficient of 0.66 and 0.7 than that from 1980 to 1985 . Specially speaking, the role of the subsidy policy in promoting grain yield has not fully reflected, in part, because Anhui had began the inter-provincial co-harvesting services in addition to completing self-harvesting since 1990s.

More interestingly, the negative significant relationship between MCI and per capita grain production in 1999 has had no statistically significant only with smaller negative correlation in 2008 (Table 4). The result partly indicates that the degree of grain specialization has been increased, especially in northern Anhui which is focused on wheat and soybean, among which wheat production there accounts for $90 \%$ of that of whole Anhui. It cannot be ignored that the protection of water resources and irrigation facilities is also closely associated with the output of grain, as shown in Table 4 which reflects three important indexes, including "irrigated area", "farmland area of stabilizing yield" and "electromechanically irrigated area". In accordance with the appeals of some scholars and government officers, the water conservancy and irrigation facilities in Anhui have had no significant changes since 1990s (Guan et al., 2009).

Table 4. Pearson's correlation between grain production and influencing factors for Anhui's 61 counties, 1999 and 2008

\begin{tabular}{lcc}
\hline & $\begin{array}{c}\text { Per capita grain production } \\
\text { in } 1999\end{array}$ & $\begin{array}{c}\text { Per capita grain production } \\
\text { in } 2008\end{array}$ \\
\hline Per capita power of agricultural machinery & $.659(* *)$ & $.698(* *)$ \\
per capita consumption of chemical fertilizers & $.722(* *)$ & $.704(* *)$ \\
Per capita cultivated land & $.833(* *)$ & $.876(* *)$ \\
MCI & $-.288(*)$ & -.172 \\
Per capita irrigated area & $.754(* *)$ & $.738(* *)$ \\
Per capita farmland area of stabilizing yield & $.619(* *)$ & $.637(* *)$ \\
Per capita electromechanically irrigated area & $.618(* *)$ & $.657(* *)$ \\
\hline
\end{tabular}

** Correlation is significant at the 0.01 level (2-tailed); * Correlation is significant at the 0.05 level (1-tailed); N=61 Source: Calculated by authors from NBS, 2000 and 2009 


\subsection{The Effect of Natural Disasters on Grain Production during Agricultural Reform Process}

Located in the transition zone between North China and South China, Anhui Province is accompanied by the flood from Yangtze River, Huaihe river basin low-lying and ecological deterioration, hence having a high frequency of natural disasters with the geographic wide-ranging impact. "One drought every three years, one flood every four years, and more serious results caused by droughts than floods" is a vivid portray of Anhui's droughts and floods which take place in most parts of Anhui (NBS, 2010). Ever since the ancient times, Anhui has been known as one of the "disaster-prone provinces". The high frequency of natural disasters in Anhui, mainly including serious droughts and floods, has made a great impact on grain production. For example, 1985's flood in Anhui directly led to a sharp decline of grain yield from 22.02 billion kilograms in 1984 to 21.68 billion kilograms in 1985 with a growth rate of $-1.6 \%$ (NBS, 1985; 1986). In order to further illuminate the negative impact of droughts and floods on grain production, the flood in 2003 and the drought in 2008 are contrasted as follows.

In 2003 which is regarded as a natural disaster-stricken year, the scab of wheat and the sclerotinia rot of colza had come into vogue as a result of continuous low temperature and cold rain in spring. Heavy rain and hail in summer become a catastrophe so that serious floods took place at the watershed of Huaihe River and Chuhe River. At the same time, due to a large area of paddy suffering from a damage caused by high temperature, less than $50 \%$ of the planted paddy got ripe finally. As a result, a large area of paddy, maize, cotton and peanut was cut so that Anhui's annual grain yield felled by $20 \%$, where the crops of 36.24 million mu were affected.

Using the optimal spatial interpolation of city precipitation by ARCGIS software (Figure 5). Table 5 shows the correlation between the grain production per mu and the precipitation for 1999 and 2003, where 1999's precipitation is regarded as relatively normal. With four times' durative precipitation in June and July of 2003, the serious floods remarkably affected the yield of paddy and cereal per mu (including wheat, paddy and maize) (Table 5). For all the year round, floods mainly significantly affected wheat production due to durative cold rain in spring and serious floods in June of 2003 (Table 5). The influence of summer's flood and spring's durative cold rain on grain output in 2003 can also be observed from Pearson correlation coefficient between per capita grain production and the related socioeconomic indexes, which is significantly lower than that in the period from 1999 to 2008 (Table 6).

On the contrary, even though experiencing a rare drought in history in 1999, Anhui's grain output continued to maintain its growth for the sixth year since 2004. Despite of the positive contribution of local government to combat droughts, objectively speaking, one of the most important reasons comes from the tremendous enthusiasm of peasants under the encouragement of a series of policies related to top-down agricultural reform.
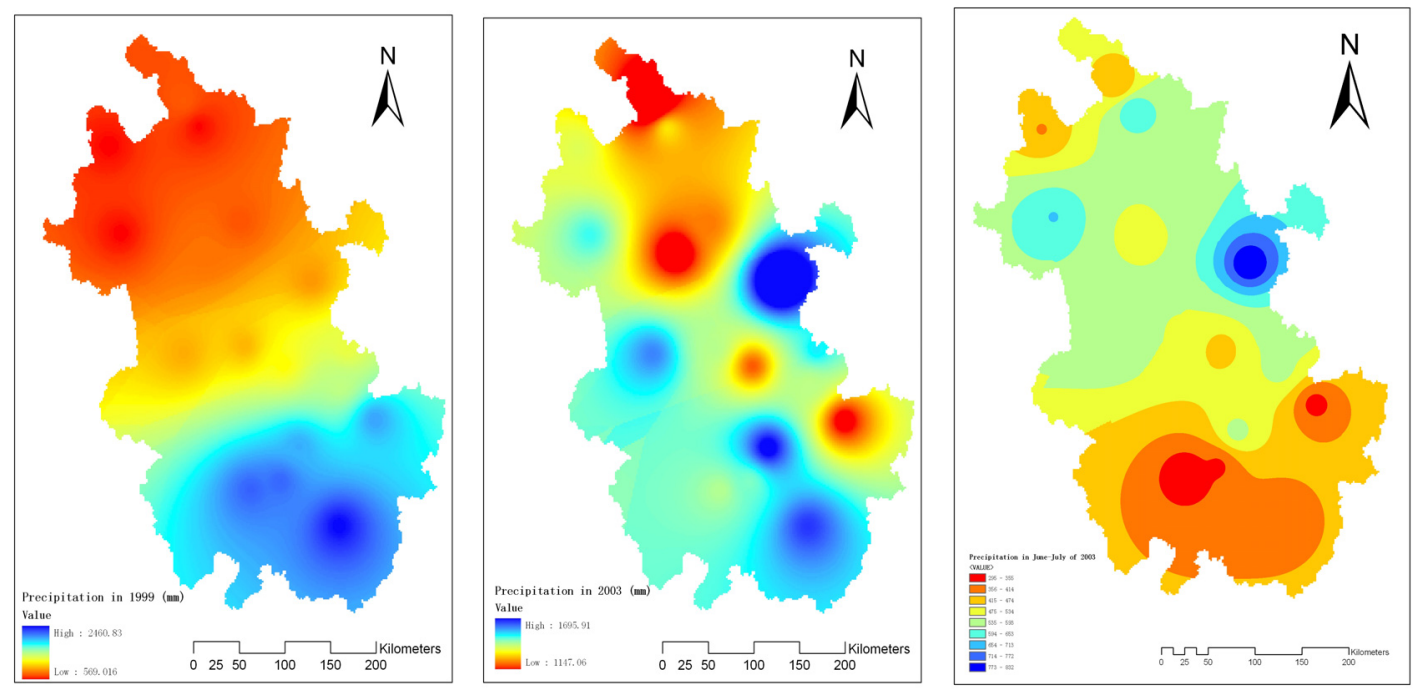

Figure 5. Map of Precipitation Distribution

Source: Mapped by ARCGIS' spatial interpolation method 
Table 5. The influence of disastrous precipitation on mean grain yield, 2003

\begin{tabular}{lcc}
\hline & $\begin{array}{c}\text { Pearson correlation with } \\
\text { Precipitation in 2003 }\end{array}$ & $\begin{array}{c}\text { Pearson correlation with Precipitation } \\
\text { in June-July 2003 }\end{array}$ \\
\hline grain yield per mu & .028 & -.480 \\
cereal yield per mu & -.043 & $-.582\left(^{*}\right)$ \\
paddy yield per $\mathrm{mu}$ & -.391 & $-.628\left(^{* *}\right)$ \\
wheat yield per $\mathrm{mu}$ & $-.500(*)$ & .099 \\
maize yield per $\mathrm{mu}$ & -.324 & -.262 \\
\hline
\end{tabular}

Significance Levels * represents significance at 0.05 or better, ${ }^{* *}$ represents significance at 0.01 or better; $N=17$ Source: Calculated by authors from NBS, 2004

Table 6. Pearson's correlation between grain production and the related indexes for Anhui's 61 counties, 1999, 2003 and 2008

\begin{tabular}{lccc}
\hline & $\begin{array}{c}\text { Per capita grain } \\
\text { production in 1999 }\end{array}$ & $\begin{array}{c}\text { Per capita grain production } \\
\text { in 2003 (disaster year) }\end{array}$ & $\begin{array}{c}\text { Per capita grain } \\
\text { production in 2008 }\end{array}$ \\
\hline Per capita power of agricultural machinery & $.659(* *)$ & $.580\left(^{* *}\right)$ & $.698(* *)$ \\
Per capita consumption of chemical fertilizers & $.722(* *)$ & $.576(* *)$ & $.704(* *)$ \\
Per capita cultivated land & $.833(* *)$ & $.693(* *)$ & $.876(* *)$ \\
MCI & $-.288(*)$ & -.018 & -.172 \\
Per capita irrigated area & $.754(* *)$ & $.586(* *)$ & $.738(* *)$ \\
Per capita farmland area of stabilizing yield & $.619(* *)$ & $.541(* *)$ & $.637(* *)$ \\
Per capita electromechanically irrigated area & $.618(* *)$ & $.456(* *)$ & $.657(* *)$ \\
\hline
\end{tabular}

Significance Levels * represents significance at 0.05 or better, ${ }^{* *}$ represents significance at 0.01 or better; $N=61$ Source: Calculated by authors from NBS, 2000, 2004 and 2009

\section{Conclusions}

According to these significant differences for key initiators, guides, designers and organizers, two stages of agricultural reforms occurring respectively in earlier 1980s and after China's entry into WTO are defined respectively as the bottom-up stage and the top-down stage in this article. Based on a comprehensive quantitative-qualitative analysis on Anhui's grain production in response to the full implementation of the bottom-up and top-down agricultural reforms, some main conclusions are drawn as follows:

1) In the agricultural society during the bottom-up agricultural reform, grain production growth made great contributions to solving China's grain food crisis and feeding urban and rural people. While in the industrialized society at the top-down stage, grain production has failed to exert a greater contribution to regional economy, hence having less contribution to grain growth to family. But the top-down agricultural reform has been playing a leading role in the improvement of China's grain food security.

2) In common, among all sorts of socioeconomic influencing factors, grain planting area and cultivated land have been the leading driving forces for grain growth, and chemical fertilizers and mechanization have also exerted significant positive impacts on grain yield. Yet, water conservation and irrigation conduction cannot be neglected in spite of abundant water resources.

3) In contrast, during the bottom-up agricultural reform, chemical fertilizers and irrigation played the most important role, followed by the factor of arable land and then mechanization, but as to the top-down agricultural reform, the main influencing factors in sequence include respectively arable land, mechanization, chemical fertilizers and irrigation. More specially, chemical fertilizers, which used to be an important factor for 1980s' grain yield, have had a very limited contribution to modern grain production under the law of diminishing returns. Meanwhile, compared to that in earlier 1980s, irrigation has had less contribution to grain production with better irrigation facilities after China's entry into WTO. Similarly, agricultural mechanization facilitated grain output at the earlier stage of mechanization while modern agricultural mechanization, which is sufficient for grain production under the top-down subsidy policies, only play a slightly greater role in promoting grain 
yield than in the bottom-up agricultural reform

4) In the bottom-up agricultural reform, improved MCI facilitated the diversity of agriculture, while with agricultural modernization and top-down rural reform, in addition to diversified cultivation, agricultural specialization and clustering will achieve greater development.

5) Natural disasters including serious droughts and floods have been playing a special role in the stagnation and countermarch of grain growth. Nowadays, under the leadership of local government and the guidance of China's central government, the active participation of peasants has weakened the impacts caused by natural disasters on grain production.

Anyway, as for the top-down and bottom-up agricultural reforms, this paper cannot conclude which is better. It is very clear that both stages have made great contributions at their specific historical stages regardless of some of different drivers. With the lower comparative advantage of agriculture due to China's industrialization and urbanization, it is worth our serious consideration whether it is necessary for China central government to attach greater importance to more top-down agricultural reforms to achieve grain growth.

\section{Acknowledgements}

The authors wish to acknowledge research funding provided by National Social Science Foundation of China (09XJY030), and the financial support provided by Sichuan Agricultural University is gratefully acknowledged.

\section{References}

Barr, T. N. (1981). The World Food Situation and Global Grain Prospects. Science, 214, 1087-1095. http://dx.doi.org/10.1126/science.7302579

Battisti, David S., \& Naylor, Rosamond L. (2009). Historical Warnings of Future Food Insecurity with Unprecedented Seasonal Heat. Science, 323, 240-244. http://dx.doi.org/10.1126/science.1164363

Blandford, David. (1983). Instability in World Grain Markets. Journal of Agricultural Economics, 34(3), 379-395. http://dx.doi.org/10.1111/j.1477-9552.1983.tb01011.x

Brown, Lester R. (1994). Who will feed China? World Watch, September/October, 10-19.

Brown, Lester R. (1995). Who will feed China? Wake-up call for a small planet. New York: W.W. Norton \& Company.

Brown, Lester R., \& Halweil, Brian. (1998). China's Water Shortage Could Shake World Food Security. World Watch, July/August, 10-16.

Carter, Colin A., \& Zhong, Fu-Ning. (1988). China's Grain Production and Trade: An Economic Analysis. Boulder CO: Westview Press.

Chen, Baiming. (1997). Comment on 'Who Will Feed China'. Chinese Geographical Science, 7(1), 11-18. http://dx.doi.org/10.1007/s11769-997-0067-0

Cui, Shunji, \& Kattumuri, Ruth. (2010). Cultivated Land Conversion in China and the Potential for Food Security and Sustainability. Asia Research Centre Working Paper, 1-34.

Duan, Xiufang, \& Dwyer, Wayne. (2008). Rethinking China's domestic agriculture support measures under WTO protocols. Journal of the Asia Pacific Economy, 13(1), 89-106. http://dx.doi.org/10.1080/13547860701733115

Fan, Ming, \& Cheng, Feng. (2006). China Grain Productivity Analysis of China. China Land Science, 20(4), 46-51. (in Chinese)

Guan, Shuqi, Wang, Jinglian, \& Jiang, Weiyang. (2009). Small Water Conservancy Facilities is an Urgent Need to Strengthen. Retrieved July 16, 2010, from http://www.counsellor.gov.cn/content/2009-09/25/content_7063.htm (in Chinese)

Ho, Peter, Eyferth, Jacob, \& Vermeer, Eduard B. (2004). Rural Development in Transitional China: The New Agriculture. Portland, OR: Frank Cass.

Khush, Gurdev S. (1999). Green Revolution: Preparing for the 21st Century. Genome, 42(4), 646-655. http://dx.doi.org/10.1139/gen-42-4-646

NBS (National Bureau of Statistics). (1979-2010). China Statistical Yearbook 1979-2010. Beijing, China: China Statistics Press. (in Chinese)

NBS (National Bureau of Statistics). (2010). Rural Reform for 30 years: Retrospect and Prospect. Retrieved 
September 2, 2010, from http://www.ahdc.gov.cn/dt2111111141.asp?DocID=2111119777 (in Chinese)

Neumann, Kathleen, Verburg, Peter H., Stehfest, Elke, et al. (2010). The Yield Gap of Global Grain Production: A Spatial Analysis. Agricultural Systems, 103(5), 316-326. http://dx.doi.org/10.1016/j.agsy.2010.02.004

OECD (Organisation for Economic Cooperation and Development). (2005). Agricultural Policy Reform in China. OECD Observer, October, 1-7.

Parry, Martin, Rosenzweig, Cynthia, Iglesias, Ana, et al. (1999). Climate Change and World Food Security: A New Assessment. Global Environmental Change, 9(Supplement 1), S51-S67. http://dx.doi.org/10.1016/S0959-3780(99)00018-7

Prosterman, R. L., \& Hanstad, T. (1996). Can China feed itself? Scientific American, November, 90-96. http://dx.doi.org/10.1038/scientificamerican1196-90

Rode, Sanjay. (2011). Inequality in Food Grains Production in Maharashtra: A Study of Vidarbha Region. Journal of Agricultural \& Economics, 6(2), 7-17.

Rozelle, Scott D., \& Sumner, Daniel A. (2003). Agricultural Trade and Policy in China. Aldershot, UK: Ashgate Publishing Limited.

Rozelle, Scott, \& Veeck, Gregory. (1997). The Impact of Environmental Degradation on Grain Production in $\begin{array}{lllll}\text { China, } & \text { Economic }\end{array}$ http://dx.doi.org/10.1111/j.1944-8287.1997.tb00084.x

Shenon, Philip. (1994). Good Earth is Squandered. Who'll Feed China? New York Times, Sept. 21, 1994, p. A10, national edition.

Smil, Vaclav. (1996). Is there enough Chinese food? The New York Review, February, 32-35.

Thompson, Louis M. (1975). Weather Variability, Climatic Change and Grain Production. Science, 188, 535-541. http://dx.doi.org/10.1126/science.188.4188.535

Veeck, Gregory, \& Shui, Wei. (2011). China's Quiet Agricultural Revolution: Policy and Programs of the New Millennium. Eurasian Geography and Economics, 52(2), 242-263. http://dx.doi.org/10.2747/1539-7216.52.2.242

Veeck, Gregory. (2009). China's Exports and Imports of Agricultural Products under the WTO. Eurasian Geography and Economics, 49(5), 569-585. http://dx.doi.org/10.2747/1539-7216.49.5.569

Verburg, Peter H., Chen, Youqi, \& Veldkamp, Tom. (2000). Spatial Explorations of Land Use Change and Grain Production in China. Agriculture, Ecosystems \& Environment, 82(1-3), 333-354. http://dx.doi.org/10.1016/S0167-8809(00)00236-X

Wang, Hongguang, Wang, Xiaofang, \& Wang, Zhixue. (2011). Chinese Food Problem can Worry about is not Terrible: A Discussion with Dr. Lester Brown, "The Future, Who Will Feed China”. China Soft Science, 6, 97-103. (in Chinese)

Wang, Qingbin, Halbrendt, Catherine, \& Johnson, Stanley R. (1996). Grain Production and Environment Management in China's Fertilizer Economy. Journal of Environmental Management, 47(3), 283-296.

Wen, Tiejun. (2001). Analysis on the Six-times Volatility of China's Grain Supply and Demand for 50 Years. Journal of Shandong Agricultural Administrators 'College, 2, 7-9. (in Chinese)

Xie, Ru. (1996). Grain Issues in China Should be Treated in a Correct Way: Answers to Brown's 'Who Will Feed China'. Contemporary Finance and Economics, 8, 10-14. (in Chinese)

Xinhua News Agency. (2005). China's Legislature Abolishes 2,600-year-old Agricultural Tax. Peoplenet.com. December 30, 2005. Retrieved August 22, 2009, from http://english.peopledaily.com.cn/200512/30/eng20051230_231752.html

Xinhua News Agency. (2007). Why did China's Rural Reform Begin and Succeed in Anhui Province? xinhua.org, December 6, 2007. Retrieved December 20, 2009, from http://news.china.com/zh_cn/news100/11038989/20071206/14528849.html (in Chinese)

Yang, Hong. (1999). Growth in China's Grain Production 1978-1997: A Disaggregate Analysis. World Development, 27(12), 2137-2155. http://dx.doi.org/10.1016/S0305-750X(99)00107-2

Yao, Shujie, \& Liu, Zinan. (1998). Determinants of Grain Production and Technical Efficiency in China. Journal of Agricultural Economics, 49(2), 171-184. http://dx.doi.org/10.1111/j.1477-9552.1998.tb01262.x 
Yao, Shujie. (1994). Agricultural Reforms and Grain Production in China. New York: St. Martin's Press.

Zhai, Rongxin, \& Liu Yansu. (2008). Changes in Regional Pattern for Grain Production in China since the 90's of 20 Century. Chinese Journal of Agricultural Resources and Regional Planning, 29(6), 49-54. (in Chinese)

Zhang, Hongye, Li, Xiaofeng, \& Shao, Xiaomei. (2006). Impacts of China's Rural Land Policy and Administration on Rural Economy and Grain Production. Review of Policy Research, 23(2), 607-623. (in Chinese)

Zhang, Jing, Yang, Yanzhao, \& Wang, Jingping. (2007). Study on the Types of Grain Production Changes in China. Chinese Journal of Agricultural Resources and Regional Planning, 28(3), 11-16. (in Chinese) 